\title{
EFFECT OF ANTI-WEAR ADDITIVE ON CUTTING TOOL AND SURFACE LAYER OF WORKPIECE STATE UNDER MQCL CONDITIONS
}

\author{
Radoslaw Maruda, Stanislaw Legutko, Grzegorz Krolczyk, Czeslaw Lukianowicz, Antun Stoić
}

Original scientific paper The work presents the results of investigation of the influence of anti-wear additive Crodafos EHA-LQ-(MH) added to the emulsion mist on the condition of machined surface of 1.4310 stainless steel after turning. The investigation included the comparison of the following cutting conditions: dry machining, cooling by the MQCL method and cooling by the MQCL method with Crodafos EHA-LQ-(MH). In the paper, the influence of the Anti-Wear (AW) additive on the roughness parameter $R a$ of the machined surface for various cutting speeds, $v_{c}$, and mass flow of the emulsion $E$ has been shown. It was found that the MQCL+AW method decreases the $R a$ parameter values by $14 \%$ to $35 \%$ in comparison with dry cutting and by $17 \%$ in comparison with MQCL method.The machined material and the rake face of the cutting wedge have been subjected to micro X-ray spectroanalysis. Chemical analysis of the cutting wedge and the surface layer of the machined material has been performed. The results show that water dropletts in MQCL method are very good transport facility for active compounds of AW additive that consequently form the dry-film lubricant on the machined surface.

Key words: Anti-Wear additives; MQCL; stainless steel; surface roughness; turning

\section{Utjecaj dodatka protiv trošenja emulziji na stanje reznog alata i površine obratka u MQCL uvjetima obrade}

Izvorni znanstveni članak

Rad prikazuje rezultate istraživanja utjecaja dodatka emulziji radi manjeg trošenja reznog alata oznake Crodafos EHA-LQ-(MH) na stanje obrađene površine korozijski postojanog čelika 1.4310 nakon tokarenja. Istraživanje sadrži usporedbu sljedećih uvjeta obrade: suha obrada, hlađenje MQCL metodom i hlađenje MQCL metodom s aditivom Crodafos EHA-LQ-(MH). U radu se prikazuje utjecaj AW dodatka emulziji na hrapavost obrađene površine mjeren parametrom $R a$ pri različitim brzinama rezanja $v_{\mathrm{c}}$ i masenim protocima emulzije $E$. Ustanovljeno je da se MQCL+AW metodom smanjuju vrijednosti $R a$ parametra za $14 \%$ do $35 \%$ u usporedbi sa suhom obradom i za $17 \%$ u usporedbi s MQCL metodom. Obrađena površina obratka i stražnja površina alata snimana je mikro X-zračenjem i provedena je spektroanaliza. Provedena je i kemijska analiza rezne oštrice i površinskih slojeva obrađene površine. Rezultati pokazuju da su vodene kapljice u MQCL metodi vrlo dobro transportno sredstvo aktivnih sastojaka AW aditiva koje stvaraju suhi sloj maziva na obrađenoj površini.

Ključne riječi: dodatci protiv trošenja; hrapavost; korozijski postojani čelik; MQCL (minimalna količina rashladnog podmazivanja); tokarenje

\section{Introduction}

The application of cooling fluids and hydraulic oils in the processes of machining is related to the desire of reducing the wear of the cutting tools. However, environmental aspects concerning the utilization of the cooling- lubricating liquids are becoming an important problem. Therefore, in parallel to the optimization of the production process, industry is aiming at reduction of the impact of its activity on the environment. Investigation works performed so far have shown that the traditional way of supplying the cooling-lubricating liquid to the cutting zone is unsatisfactory and ineffective [1]. That is why the MQL (minimum quantity of lubrication) or MQCL (minimum quantity of cooling and lubrication) methods have been introduced. The methods are effective and, first of all, more environment friendly [2]. The methods are applied in various machining processes, such as milling, turning, drilling and grinding [3-7]. They result in, among others, reduction of the cutting force [6], temperature in the cutting zone [8], extension of the tool life $[8,9]$, as well as reduction of the machined surface roughness $[8 \div 12]$. The goal of machining process is to manufacture products with high surface quality at low cost. The above can be obtained by reducing the expenses related to the use of cooling and lubricating substances with simultaneous formation of a thin anti-friction film in the tool-chip interface $[13,14]$. This results in deposition of surface active components contained in the modifiers on the surface of the machined material and on the rake face of the cutting tool. The elements constituting such compounds are most often sulphur, calcium, lead and other elements applied as EP and AW additives [15]. On the one hand, those additives reduce the friction coefficient on the wedge contact surfaces with simultaneous reduction of the wear of those surfaces as a result of formation of hard lubricants, e.g. sulphides and phosphates. On the other hand AW and EP additives present in the emulsion mist result in reduction of the cutting force and temperature [16]. The objective of the present work is to determine the influence of the cutting parameters, mass flow of emulsion with AW additive and volume flow of air on the roughness of stainless steel surface of workpiece and on the characteristics of the surface layer of the cutting wedges applied.

\section{Methodology of investigation}

The material used in the investigation was 1.4310 stainless steel (acc. to DIN EN 10088-1) with the structure of alloy martensite. Its tensile strength is 650 $\mathrm{MPa}$, elongation $40 \%$, Brinell hardness $230 \mathrm{HB}$. Coated carbide inserts with ISO code, SNUN120408, were used in this study, clamped in the tool shank of CSDBM2020M12. The inserts had a one-layer CVD coating, $\operatorname{Ti}(\mathrm{C}, \mathrm{N})$, about $2 \mu \mathrm{m}$ thick, on a cemented carbide substrate and maximum working temperature of $900{ }^{\circ} \mathrm{C}$.

In the MQCL method, concentrate of OPORTET RG2 emulsion was used as the active medium. Its concentration in water was $4 \%$. Crodafos EHA-LQ-(MN) phosphorate ester was used as modifier for the emulsion mist. In accordance with the producer's recommendation, concentration of $5 \%$ was applied. For the creation of the 
emulsion mist, Micronizer 1 LN Micro Unit Wlenox Nozzle device provided with air flow control nozzles and emulsion flow control nozzles was used. The device was connected to a compressor. The pressure generated by the compressor was $2 \mathrm{MPa}$.

Basing on the industrial recommendations and on the conclusions from authors earlier investigations [4, 17, 18], the range of machining parameters has been selected: $v_{\mathrm{c}}=$ $50 \div 300 \mathrm{~m} / \mathrm{min}, f=0,1 \div 0,5 \mathrm{~mm} / \mathrm{rev}, a_{\mathrm{p}}=1 \mathrm{~mm}$.

For the creation of the emulsion mist, the following ranges were used: mass flow of emulsion, $E=1,8 \div 3,6$ $\mathrm{g} / \mathrm{min}$, volume flow of air, $P=4,5 \div 6,7 \mathrm{~m}^{3} / \mathrm{h}$ and nozzle distance from the cutting zone $L=0,4 \mathrm{~m}$. The method of Parameter Space investigation has been applied in the tests [4].

\section{Surface roughness measurement}

Measurements of roughness have been performed by means of profile measurement gauge, TR-200. The results of the measurements of roughness parameters have been subjected to statistical processing with the use of Statistic software and then, basing on mathematical processing, equations of multidimensional regression have been obtained; the equations, including the coefficient of multidimensional correlation $r$ for each equation, can be found in Tab. 1 .

Table 1 Equations of regression and the value of multidimensional correlation coefficient

\begin{tabular}{|c|c|c|c|}
\hline & Dry & MQCL & MQCL + AW \\
\hline \multirow{3}{*}{$R a$} & $R a=87,1 \cdot v_{\mathrm{c}}^{-0,325}$ & $R a=258 \cdot v_{\mathrm{c}}^{-0,304}$ & $R a=635 \cdot v_{\mathrm{c}}^{-0,437}$ \\
$\mu \mathrm{m}$ & $\cdot f^{1,067}$ & $f^{1,515} \cdot P^{-0,150}$ & $\cdot f^{1,263} \cdot P^{-0,372}$ \\
& & $\cdot E^{-0,686}$ & $\cdot E^{-0,740}$ \\
& $r=0,9658$ & $r=0,9892$ & $r=0,9956$ \\
\hline
\end{tabular}

In Fig. 1, one can find curves of $R a$ parameter variations as a function of the variable cutting speed $v_{\mathrm{c}}$ according to the regression equations in the machined surface of 1.4310 stainless steel elements. Fig. 2 shows the curves of the $R a$ parameter variations as a function of mass flow of emulsion $E$.

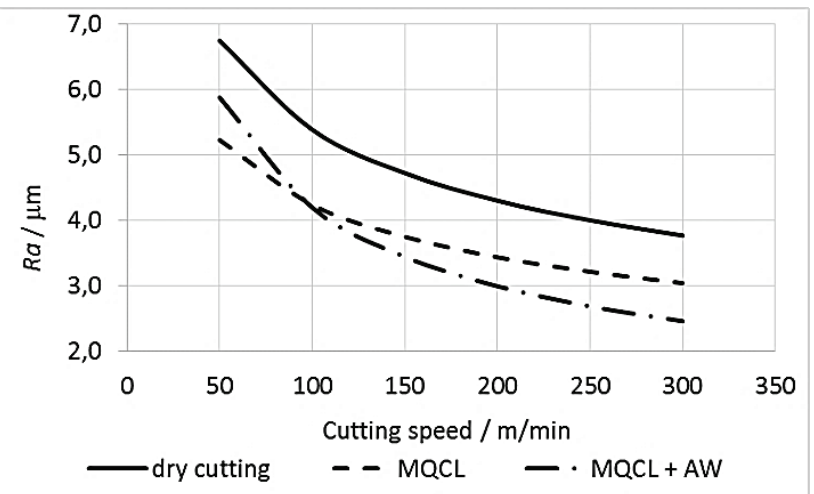

Figure 1 The influence of cutting speed $v_{\mathrm{c}}$ on the $R a$ parameter of machined surface of 1.4310 stainless steel after turning with $f=0,3 \mathrm{~mm} / \mathrm{rev} ; P=5,5 \mathrm{~m}^{3} / \mathrm{h}$ and $E=2,5 \mathrm{~g} / \mathrm{min}$

The lowest values of the $R a$ parameter have been obtained for $v_{\mathrm{c}}<80 \mathrm{~m} / \mathrm{min}$ in the MQCL method and, above that cutting speed, for cooling in the MQCL + AW conditions (Fig. 1). The value of $R a$ parameter with
MQCL + AW cooling method decreases by $14 \%$ to $35 \%$ as compared to dry machining. In the case of MQCL method decreasing is equal to $17 \%$ for cutting speed more than $80 \mathrm{~m} / \mathrm{min}$, but when cutting speed is less than $80 \mathrm{~m} / \mathrm{min}, R a$ parameter increases by $12 \%$. It affects cutting conditions: decreases the friction coefficient on the chip - rake face interface and the wear rate of contact surfaces.

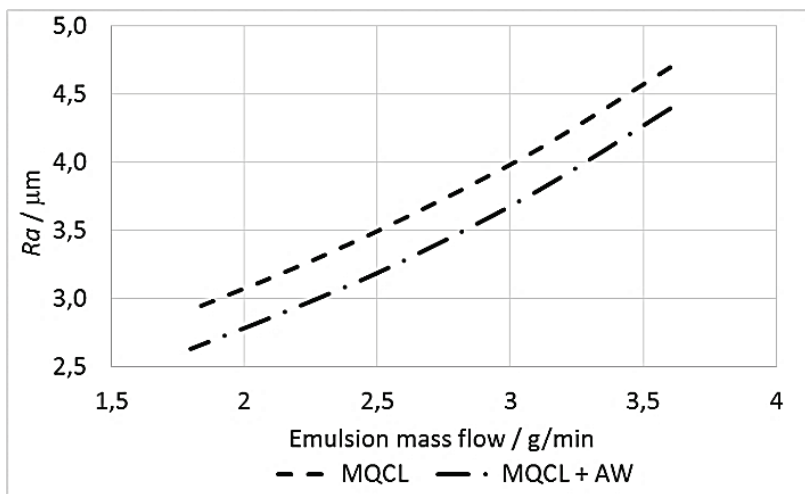

Figure 2 The influence of emulsion mist flow $E$ on the $R a$ parameter of the machined surface of 1.4310 stainless steel after turning with $v_{\mathrm{c}}=150$ $\mathrm{m} / \mathrm{min} ; f=0,3 \mathrm{~mm} / \mathrm{rev}$ and $P=5,5 \mathrm{~m}^{3} / \mathrm{h}$

It has been found that the value of the $R a$ parameter grows with the increase of the mass flow of emulsion (Fig. 2).

The results obtained are in conformance with the results of investigations of the influence of emulsion flow on the surface roughness [19]. The lowest value has been obtained in the whole range of variable emulsion flow for the MQCL +AW method.

\section{SEM analysis}

JEOL JSM-5600LV scanning microscope coupled to an X-ray microanalyzer has been used for the analysis of the machined material surface after the process of turning and the rake face of the cutting wedge for the parameters with which the lowest values of the $\mathrm{Ra}$ parameter had been recorded $\left(v_{\mathrm{c}}=250 \mathrm{~m} / \mathrm{min}, f=0,15 \mathrm{~mm} / \mathrm{rev}, E=1,6\right.$ $\left.\mathrm{g} / \mathrm{min}, P=6,5 \mathrm{~m}^{3} / \mathrm{h}\right)$. The surface of 1.4310 stainless steel after the process of turning with MQCL + AW cooling is shown in Fig. 3; the cutting wedge rake face can be seen in Figs. 4 and 5. Traces left after evaporation of the micro droplets deposited under the conditions of MQCL cooling with the addition of an AW medium type EHA-LQ-(MH) have been observed on the whole surface of the machined material.

On the whole surface, an increased content of phosphorus has been found $(8,2 \%)$. In Fig. $3 b$, an area with clear increase of phosphorus content $(34,1 \%)$ has been distinguished. The presence of that element on the machined material surface results in reduction of the friction coefficient on the wedge contact surfaces and reduction of wear intensity due to the formation of hard lubricants on the metal [19].

No phosphate ester compounds have been found on the rake face in the chip contact zone (Fig. 5). Hard lubrication film is not formed on the coated cutting plate used in the tests. The chemical compounds contained in the EHA-LQ-(MH) additive do not remain on the coating. 
On the other hand, damage of the coating has been observed (Fig. 5 - micro area 3 ) and subjected to analysis and the results can be seen in Fig. 4. It has been found that the phosphorus compound $(7,9 \%)$ occurs in locations where the coating had been damaged (Fig. 4).
This proves that the hard lubricating film can be formed only on plates without coating, which is also evidenced in earlier investigations [14].
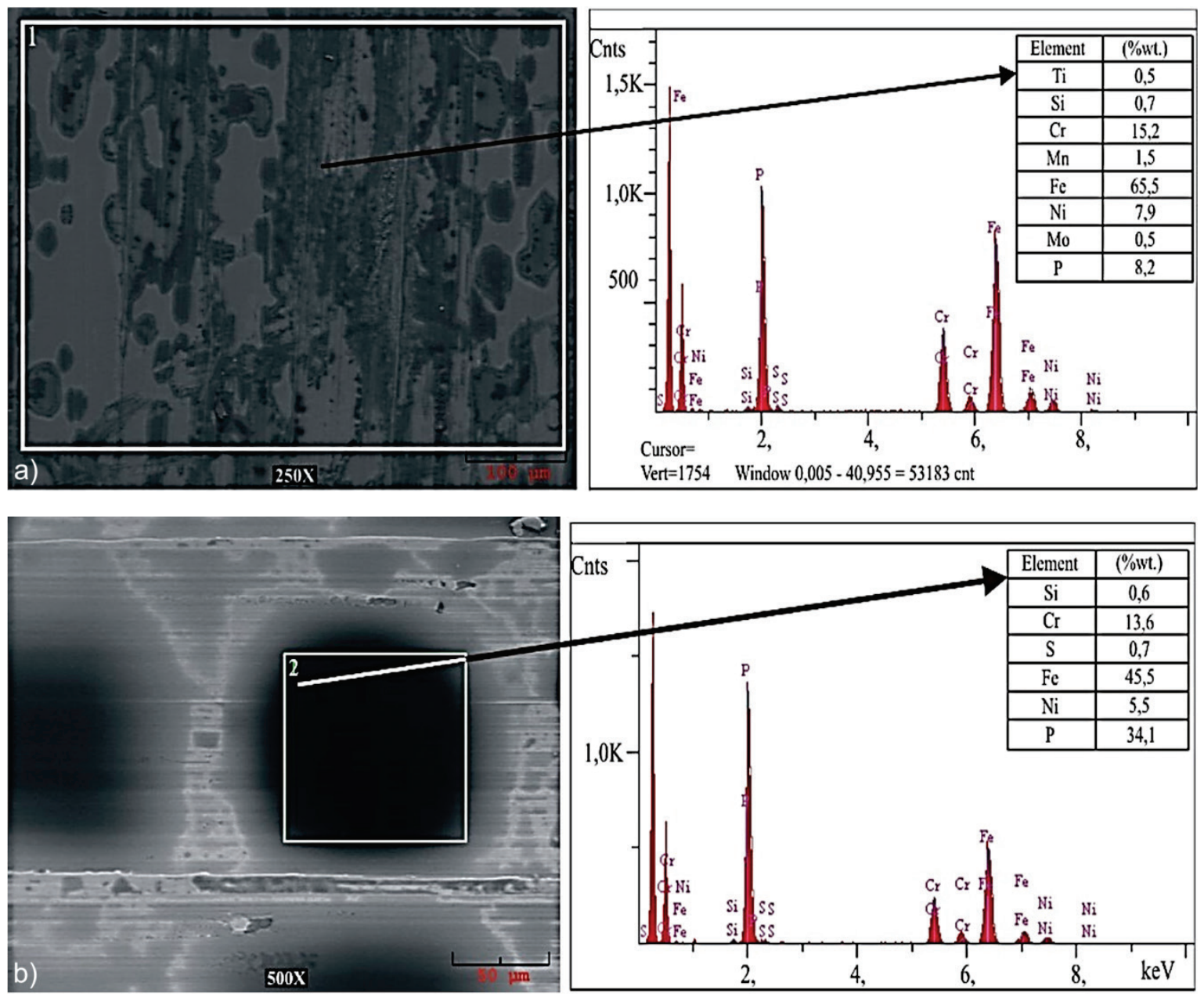

Figure 3 Analysis of the chemical composition of the machined surface after turning process under conditions of MQCL + AW cooling: a) qualitative and quantitative chemical analysis of micro area $1(250 \times$, SE detector); b) qualitative and quantitative chemical analysis of micro area $2(500 \times, \mathrm{SE}$ detector $)$

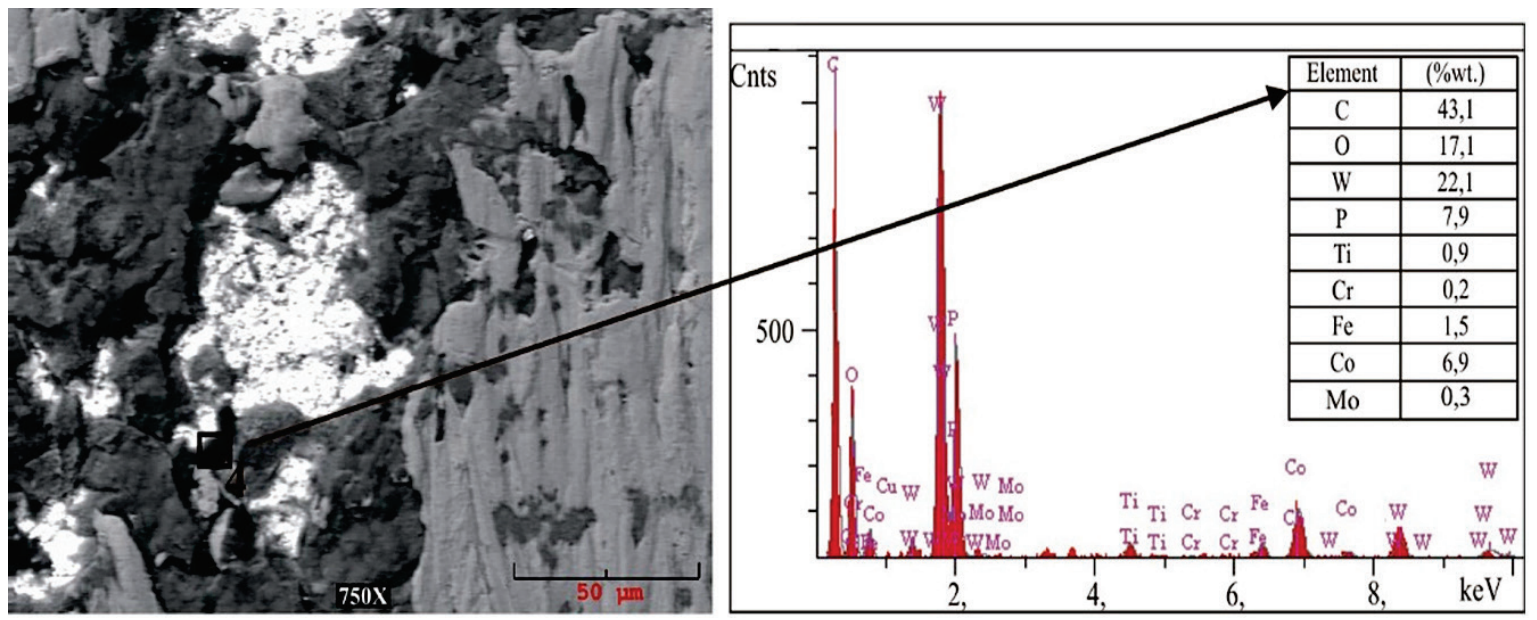

Figure 4 Qualitative and quantitative analysis of the chemical composition on the cutting wedge rake face at the point of coating damage after turning under MQCL conditions (micro area in point $4,750 \times$, SE detector) 


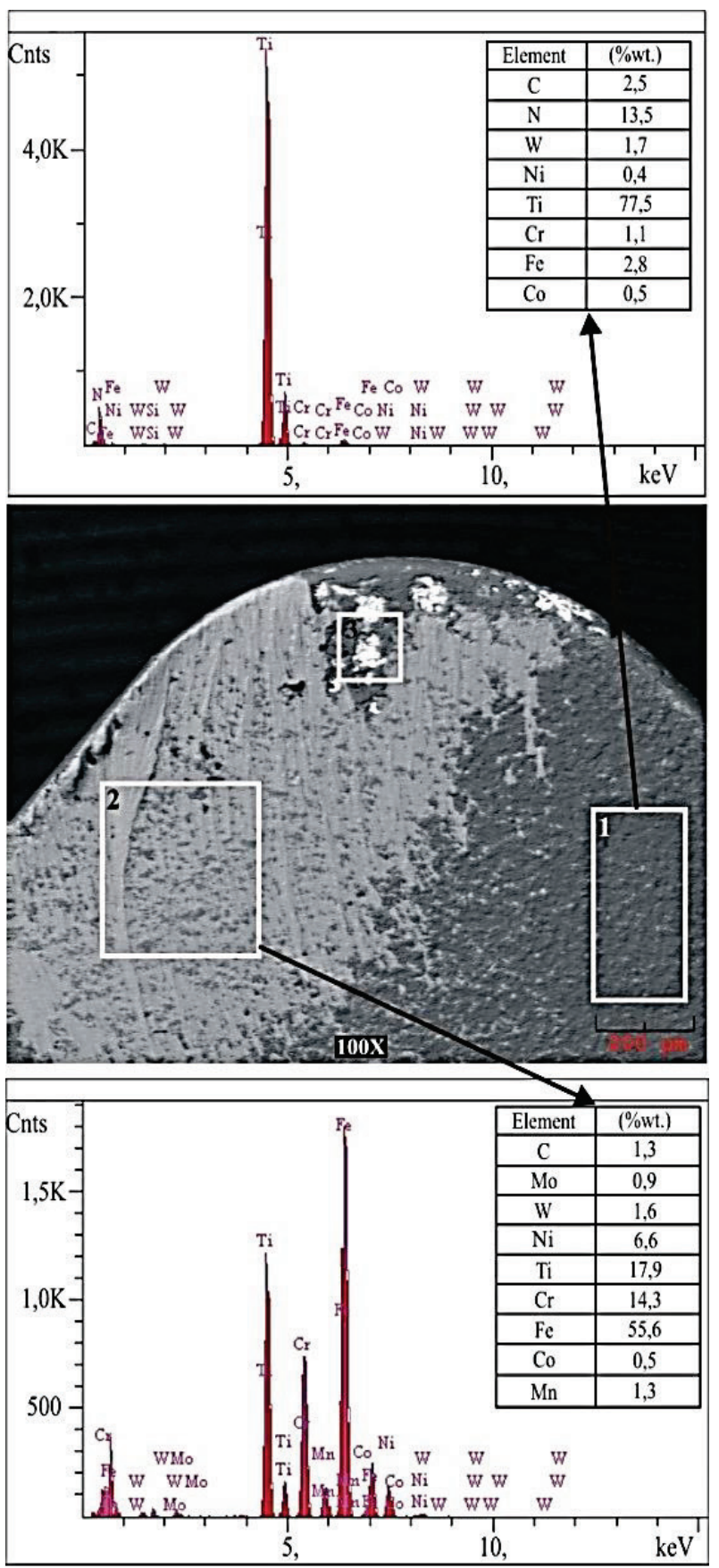

Figure 5 Qualitative and qualitative analysis of the chemical composition on the cutting wedge rake face after turning under MQCL conditions:(micro areas in point 1 and $2,100 \times$, SE detector)

\section{Conclusion}

In the conditions of emulsion mist formation, one can cause total evaporation of water from the cutting zone. Then, the active components of the anti-wear additive form a layer of hard lubricant, which can result in reduction of the friction coefficient, cutting resistance etc. From the present investigation, the following conclusions can be drawn:

1) Cooling under MQCL $+\mathrm{AW}$ conditions reduces the $R a$ parameter values by $14 \%$ to $35 \%$ and under MQCL conditions reducing is by $20 \%$ to $25 \%$ as compared to dry machining,

2) Increase of the mass flow of emulsion $E$ results in growth of the roughness of the machined surface.
3) In effectively selected conditions, one can obtain permanent lubricating film changing the tribological interaction of the machined material and the wedge material.

4) On the plate with $\operatorname{Ti}(\mathrm{C}, \mathrm{N})$ coating, lubricating film is not formed as no elements contained in the anti-wear additive have been found.

\section{References}

[1] Kramar, D.; Sekulič, M.; Jurkovič, Z.; Kopač J. The machinability of nickel-based alloys in high-pressure jet assisted (HPJA) turning. // Metalurgija. 52, 4(2013), pp. 512-514.

[2] Adler, D. P.; Hii, W. W-S.; Michalek, D. J.; Sutherland, J. $\mathrm{W}$. Examining the role of gutting fluids and efforts to address associated environmental/health concerns. // Machining Science and Technology. 10, 1(2006), pp. 2358. DOI: $10.1080 / 10910340500534282$

[3] Hadad, M.; Sadeghi, B. Minimum quantity lubricationMQL turning of AISI 4140 steel alloy. // Journal of Cleaner Production. 54, (2013), pp. 332-343. DOl: 10.1016/j.jclepro.2013.05.011

[4] Maruda, R. W.; Legutko, S.; Krolczyk, G. M. Influence of Minimum Quantity Cooling Lubrication (MQCL) on chip formation zone factors and shearing force in turning AISI 1045 steel. // Applied Mechanics and Materials. 657, (2014), pp. 43-47. DOI: www.scientific.net/AMM.657.43

[5] Rahman, M.; Senthil Kumar, A.; Salam, M. U. Experimental evaluation on the effect of minimal quantities of lubricant in milling. // International Journal of Machine Tools and Manufacture. 42, 5(2002), pp. 539-547. DOI: 10.1016/S0890-6955(01)00160-2

[6] Kalita, P.; Malshe, A. P.; Kumar, S. A.; Yoganath, V. G.; Gurumurthy, T. Study of specific energy and friction coefficient in minimum quantity lubrication grinding using oil-based nanolubricants. // Journal of Manufacturing Processes. 14, (2012), pp. 160-166. DOI: 10.1016/j.jmapro.2012.01.001

[7] Rahim, E. A.; Sasahara, H. A study of the effect of palm oil as MQL lubricant on high speed drilling of titanium alloys. // Tribology International. 44, (2011), pp. 309-317. DOI: 10.1016/j.triboint.2010.10.032

[8] Sarıkaya, M.; Güllü, A. Taguchi design and response surface methodology based analysis of machining parameters in CNC turning under MQL. // Journal of Cleaner Production. 65, (2014), pp. 604-616. DOI: 10.1016/j.jclepro.2013.08.040

[9] Sanchez, J. A.; Pombo, I.; Alberdi, R.; Izquierdo, B.; Ortega, N.; Plaza, S.; Martinez-Toledano, J. Machining evaluation of a hybrid MQL- $\mathrm{CO}_{2}$ grinding technology. // Journal of Cleaner Production. 18, (2010), pp. 1840-1849. DOI: 10.1016/j.jclepro.2010.07.002

[10] Hadad, M.; Sadeghi, B. Minimum quantity lubricationMQL turning of AISI 4140 steel alloy. // Journal of Cleaner Production. 54, (2013), pp. 332-343. DOI: 10.1016/j.jclepro.2013.05.011

[11] Saric T.; Simunovic G.; Simunovic K. Use of Neural Networks in Prediction and Simulation of Steel Surface Roughness. // International Journal of Simulation Modelling. $\quad 12, \quad 4(2013), \quad$ pp. 225-236. DOI: 10.2507/IJSIMM12(4)2.241

[12] Barkallah, M.; Louati, J.; Haddar, M. Evaluation of Manufacturing Tolerance Using a Statistical Method and Experimentation. // International Journal of Simulation Modelling, 11, 1(2012), pp. 5-16. DOI: 10.2507/IJSIMM11(1)1.194

[13] Feldshtein, E.; Maruda, R. The conditions of heat exchange when coolong of a cutting zone by emulsion mist. Archives 
of Mechanical Technology and Automation, 26 (2006) 2, 19-26.

[14] Feldshtein, E.; Maruda, R. The influence of emulsion mist modifiers on surface roughness of steel $\mathrm{C} 45$ and the state of rake face of cutting edge after turning. // Tribologia: Teoriai Praktyka. 38, 2(2007), pp. 175-185.

[15] Feldshtein, E. Some problems of metal cutting.Oficyna Wydawnicza Uniwersytetu Zielogórskiego, Zielona Gora, 2013. (in Polish).

[16] Park, K. H.; Olortegui-Yume, J.; Yoon, M. Ch.; Kwon, P. A study on droplets and their distribution for minimum quantity lubrication. // International Journal of Machine Tools and Manufacture. 50, (2010), 824-833. DOI: 10.1016/j.jimachtools.2010.05.001

[17] Krolczyk, G.; Legutko, S. Investigations into Surface Integrity in the Turning Process of Duplex Stainless Steel. // Transactions of FAMENA. 38, 2(2014), pp. 77-82.

[18] Krolczyk, G.; Nieslony, P.; Legutko, S.; Stoic, A. Microhardness changes gradient of the duplex stainless steel (DSS) surface layer after dry turning. // Metalurgija. 53, 4(2014), pp. 529-532.

[19] Stoić, A.; Duspara, M.; Kosec, B.; Stoić, M.; Samardžić, I. The influence of mixing water and abrasives on the quality of machined surface. // Metalurgija. 53, 2(2014), pp. 239242.

\section{Authors' addresses}

Radoslaw Maruda, Ph. D. Eng

University of Zielona Gora,

Faculty of Mechanical Engineering,

ul. Licealna 9, 65-417 Zielona Góra, Poland

E-mail: r.maruda@ibem.uz.zgora.pl

\section{Stanislaw Legutko, Full Prof.}

Faculty of Mechanical Engineering and Management,

Poznan University of Technology,

3 Piotrowo Street, 60-965 Poznan, Poland

E-mail: stanislaw.legutko@put.poznan.pl

\section{Grzegorz Krolczyk, Ph.D. Eng}

Opole University of Technology,

76 Prószkowska Street, 45-758 Opole, Poland

E-mail: g.krolczyk@po.opole.pl

Czeslaw Lukianowicz, Prof. nzw. dr hab. inz:

Koszalin University of Technology,

Faculty of Mechanical Engineering,

ul. Racławicka 15-17, 75-620 Koszalin, Poland

\section{Antun Stoić, Full Prof.}

Mechanical Engineering Faculty in Slavonski Brod,

J. J. Strossmayer University of Osijek

Trg Ivane Brlić Mažuranić 2

HR-35 000 Slavonski Brod, Croatia

E-mail: astoic@sfsb.hr 